\title{
Antimicrobial Qualities of Senna Alata
}

\author{
*Ehiowemwenguan, G. ${ }^{1}$, Inetianbor, J.E ${ }^{2}$. And Yakubu, J. M. ${ }^{2}$ \\ ${ }^{1 .}$ Department of Microbiology, University of Benin, P.M.B. 1154, Benin City, Nigeria \\ 2. Department of Microbiology, Federal University, Wukari, P.M.B 1020, Taraba State, Nigeria
}

\begin{abstract}
The antimicrobial activity of the root and leaf extracts of the Senna alata plant against some infectious bacteria (Escherichia coli, Proteus mirabilis, Pseudomonas aeruginosa etc) and fungi (spergillus flavus, Aspergillus niger, Candida albicans etc) as well as the physiochemical and microbiological quality of the plant was determined using the cup plate agar diffusion method. The freshly collected fresh mature leaves and roots were chopped into pieces and shade-dried at $32-35^{\circ} \mathrm{C}$ to constant weight for 5 days. $50 \mathrm{~g}$ each of the plant parts was coarsely powdered using a mortar and pestle and finely powdered using an electric blender. Each of the powdered air-dried plant material was extracted with water, acetone and methanol. All the extracts demonstrated considerable activity against both Gram negative and Gram positive bacteria and some fungi with the organic extracts showing higher activity than the aqueous extracts. Stretococus pyogenes and S. aureus were the most susceptible to all the extracts followed by Salmonella typhi and Escherichia coli. The most susceptible fungi were Cryptococcus neoformans and Candida albicans while the least susceptible was Aspergillus flavus. The minimum inhibitory concentration and minimum bactericidal concentration of the methanol extracts ranged between $3-10 \mathrm{mg} / \mathrm{ml}$ and $25-50 \mathrm{mg} / \mathrm{ml}$ for bacteria and fungi respectively. Preliminary phytochemical analysis showed that the extracts contained tannins, saponins, glycosides, flavonoids and phenols. The results obtained show the basis for the local usage of S. alata Linn as an antimicrobial. Phytochemical result showed ethanol to be a better solvent for the extraction of the bioactive agents in Senna alata which include: glycosides, alkaloids, saponins, tannins, flavonoids and volatile oil. Despite the significant progress made in microbiology and the control of microorganisms, sporadic incidents of epidemics due to drug resistant microorganisms pose an enormous threat to public health. The use of medicinal plants for antimicrobial activities needs to be given more attention.
\end{abstract}

Key Words: Antimicrobial qualities, Senna alata, phytochemicals, microorganisms

\section{Introduction}

Infectious diseases are the world's leading human and animal killers (Akinyemi, 2000). The situation is further complicated by the rapid development of multi-drug resistance to available antimicrobial agents (Alalor et al., 2012). In recent years, pharmaceutical companies have focused on developing drugs from natural products (Akinyemi, 2000). Plants still remain the most effective and cheapest alternative sources of drugs (Khan et al., 2001). Drug discovery must be a continuing process if effective chemotherapeutic agents against the rapidly increasing drug resistant bacteria and fungi are to be obtained. The local use of natural plants as primary remedies due to their pharmacological properties is quite common in Asia, Latin America and Africa (Ibrahim and Osman, 1995). Demands of traditional herbal medicines are increasing day by day not only by the developing countries but also by the developed countries throughout the world. The use of herbal medicine predates the introduction of antibiotics and predates social, economic and religious barriers (Dalziel, 1956). So studies on the ethno-botany, ethnophytopathology and ethnomedicinal uses of our wild medicinal plants and investigations regarding enhanced productivity of medicinal plants is one of the frontier areas of modern research. Ethnobotany is the study of the relationship between people and plants (El-Mahmood and Doughari, 2008). This interdisciplinary field includes studying plants as wild foods and as agricultural crops. Many species of Sennia posses anti-tumours, laxative, emetic, astringent, anti-pyretic and anti-oxidant properties (ElMahmood and Doughari, 2008). Senna alata -commonly known as "dadmari/candlebrush" having very high medicinal values like, antimicrobial property particularly against fungal dermatophytes and traditionally being used in the treatment of skin infections in man (Amon et al., 2010). Leaf extract is also credited for the treatment of constipation, inguinal hernia, intestinal parasitosis, syphilis and diabetes (Daniels et al., 2007). Leaf extract is a good antioxidant and the compound obtained from has been identified as a flavonol compound and named as 'Kaempferol' (Reezal et al., 2002). Senna alata is categorized under the family Fabaceae, a pan tropical ornamental shrub, $2-3 \mathrm{~m}$ high, widely distributed in tropical countries, stretching from Tropical America to India, Fiji, Indonesia, Malaysia and Africa. Senna alata Linn (Fabaceae) is an ornamental shrub, which grows well in forest areas of West Africa. It is locally used in Nigeria in the treatment of several infections which include ringworm, parasitic skin diseases (Palanichamy and Nagarajan, 1990). The leaves are reported to be useful in treating convulsion, gonorrhoea, heart failure, abdominal pains, oedema and is also used as a purgative 
(Daniels and Knie, 2007 ). Other scientific names of Cassia alata are Senna alata, Herpetic alata and Cassia bracteata (Abubakar et al., 2008). Cassia alata, is a herb commonly used in Nigeria for the treatment of ringworm, eczema etc. Some of the local Nigerian names are Ilesko and Rinji in Yoruba and Hausa respectively (Ibrahim and Osman, 1995). Traditionally, the leaves are pounded and rubbed on the skin to cure skin diseases (Pieme et al., 2006). Many reports have shown that some Cassia species contain antimicrobial substances, particularly Cassia alata (Villasenor et al., 2002). Recent studies revealed that Cassia alata has been proven to be effective against bacteria and fungi species (Alalor et al. 2012). They observed that the minimal inhibitory concentration (MIC) values of methanolic extracts of the leaves of Cassia alata against Staphylococcus aureus and Bacillus subtilis were $10 \mathrm{mg} / \mathrm{ml}$ and $2.5 \mathrm{mg} / \mathrm{ml}$ respectively. Idu et al., 2007 observed that preliminary phytochemical analysis of Cassia alata showed the presence of phenol, tannins, anthraquinones, saponins and flavonoids. Odunbaku and Lusanya, 2011 also corroborated this study; they further stated that, the plant also had alkaloids and cardenolides. The leaves of Cassia alata have been qualitatively analyzed for the presence of anthraquinones: rhein, aloe-emodin, chrysophanol, emodin, and physcion as well as the flavonoid, kaempferol (El-Mahmood and Doughari, 2008). A study in Malaysia (Ibrahim and Osman, 1995) reported that ethanolic extract of the Senna plant showed high activity against dermophytic fungi: Trichophyton mentagrophytes var interdigitale, T. Mentagrophytes var. mentographytes, T. rubrum and Microsporium gypseum (MIC: $125 \mathrm{mg} / \mathrm{ml}$ ) and Microsporium canis (MIC: $25 \mathrm{mg} / \mathrm{ml}$ ). There are scanty reports on the activity of Cassia alata in the form of herbal ointment preparation to the best of the authors' knowledge. The antiseptic property of Cassia alata-based herbal soap against common pathogens of the skin has been studied (Esimone et al., 2008). It has been observed that antimicrobial activity of the plants is associated with the presence of some chemical components such as phenols, tannis, saponins, alkaloids, steroids, flavonoids and carbohydrates (Ref). (Pieme et al., 2006) have investigated the antifungal and antibacterial activity of Cassia alata and have got positive results. This study is aimed at investigating the antimicrobial activity of the root and leaf extracts of the Senna alata plant against some infectious bacteria and fungi as well as determining the physiochemical and microbiological quality of the plant.

\section{Materials And Methods}

Collection and identification of plant materials: The plant Senna alata was collected in the morning from the environment of the University of Benin, Ugbowo, Benin City and were identified and authenticated by the Department of Plant Biology and Biotechnology (Herbarium section), University of Benin, Benin City. Nigeria.

\section{Preparation of Crude and Organic Extracts}

The preparation was carried out to simulate the common traditional practice where herbalists often carry out percolation with the application of heat in order to obtain decoctions containing active principles for the desired treatment. Organic solvents (acetone and methanol) were also used for possible enhancement of the extraction process. The freshly collected fresh mature leaves and roots were chopped into pieces and shade dried at $32-35^{\circ} \mathrm{C}$ to constant weight for 5 days. Subsequently, $50 \mathrm{~g}$ of each of the plant parts was coarsely powdered using a mortar and pestle and finely powdered using an electric blender. The powder was transferred into closed containers. Each of the powdered air-dried plant material was extracted with hot water, acetone and methanol. For this purpose, $25 \mathrm{~g}$ of each powdered sample was mixed with $100 \mathrm{ml}$ of de-ionized distilled water or organic solvent in a conical flask, plugged, shaken at $120 \mathrm{rpm}$ for $30 \mathrm{~min}$ and extracted by warming at $60^{\circ} \mathrm{C}$ in a shaker water bath at $50 \mathrm{rpm}$ for $2 \mathrm{~h}$. This was allowed to cool, and then filtered rapidly through four layers of gauze. The debris was extracted one more time with $100 \mathrm{ml}$ of solvent at $60^{\circ} \mathrm{C}$ in the shaker water bath at $50 \mathrm{rpm}$ for 2 $\mathrm{h}$ and filtered again. The two filtrates were then pooled and a more refined filtration was carried out using Whatman no. 1 filter paper. The resulting filtrates were then concentrated in a rotary evaporator and subsequently lyophilized to dryness for aqueous filtrates. The yield of powder was $48 \%$ (aqueous extracts), 32 $\%$ (acetone extracts) and $20 \%$ (methanol extracts) for the stem bark and $46 \%$ (aqueous extracts), $30 \%$ (acetone extracts) and $24 \%$ (methanol extracts) for the leaves.

\section{Phytochemical Analysis}

The freshly prepared extracts were subjected to standard phytochemical analysis for different constituents such as tannins, alkaloids, flavonoids, glycosides, saponins and phenols as described by Palanichamy and Nagarajan, 1990.

Test for Glycosides: To $1 \mathrm{ml}$ of the extract was added $2 \mathrm{ml}$ of acetic acid and then cooled in an ice bath at $4^{0} \mathrm{C}$. To this mixture $1 \mathrm{ml}$ of concentrated tetraoxosulphate (vi) acid $\left(\mathrm{H}_{2} \mathrm{SO}_{4}\right)$ was added dropwise. The formation of an oil layer on top of solution indicated the presence of glycosides (Odebiyi and Sofowora, 1978). 
Test for Alkaloides: To $3 \mathrm{ml}$ of the extract was added $1 \mathrm{ml}$ of $1 \%$ HCL. This resulting mixture was then treated with few drops of Meyer's reagent. The appearance of a creamy white precipitate confirmed the presence of alkaloids (Ogunkwe et al., 2004).

Test for Saponins: Five drops of olive oil was added to $2 \mathrm{ml}$ of the plant extract and the mixture shaken vigorously. The formation of a stable emulsion indicated the presence of saponins (Trease and Evans, 1996)

Test for Tannins: Two drops of $5 \% \mathrm{FeCl}_{3}$ was added to $1 \mathrm{ml}$ of the plant extract. The appearance of a dirtygreen precipitate indicated the presence of tannins (Trease and Evans, 1996)

Test for Flavonoids: To $1 \mathrm{ml}$ of the extract was added 3 drops of ammonia solution $\left(\mathrm{NH}_{3}{ }^{+}\right)$followed by $0.5 \mathrm{ml}$ of concentrated $\mathrm{HCl}$. The resultant pale brown colouration of the entire mixture indicated the presence of flavonoids (Odebiyi and Sofowora, 1978).

Test for Steroids: To $1 \mathrm{ml}$ of the plant extract was added $1 \mathrm{ml}$ of concentrated tetraoxosulphate (vi) acid $\left(\mathrm{H}_{2} \mathrm{SO}_{4}\right)$. A red colouration confirmed the presence of steroids (Trease and Evans, 1996).

Test for Resins: To $5 \mathrm{ml}$ of the extract was added $5 \mathrm{ml}$ of copper acetate solution. The mixture was shaken vigorously and allowed to separate. The appearance of a reddish-brown precipitate indicated the presence of resins (Elmahmood and Doughari, 2008).

\section{Test organisms}

Bacterial isolates of Escherichia coli, Proteus mirabilis, Pseudomonas aeruginosa, Salmonella typhi and Shigella flexneri, Staphylococcus aureus and Streptococcus pyogenes and the fungal isolates of Aspergillus flavus, Aspergillus niger, Candida albicans and Cryptococcus neoformans used for this work were sourced from the Department of Medical Microbiology, University of Benin, Teaching Hospital (UBTH), Benin City, Nigeria. All the pure cultures were suspended in nutrient broth and incubated at $37^{\circ} \mathrm{C}$ for $18 \mathrm{~h}$. Mueller Hinton agar (MHA) and Nutrient agar were used in the test for antibacterial activity while potato dextrose agar (PDA) was used in the test for antifungal activity.

\section{Determination of antimicrobial activity}

Antimicrobial activity of the aqueous and organic extracts of the plant sample was evaluated by the cup plate agar diffusion method (Ibrahim and Osman, 1995). Bacterial cultures were adjusted to 0.5 McFarland's turbidity standard and inoculated onto MHA plates (diameter $15 \mathrm{~cm}$ ). Prior to the determination of antimycotic activity, all the fungal isolates were first adjusted to a concentration of $106 \mathrm{spores} / \mathrm{ml}$. Cultures of Candida albicans were suspended in sterile solution of $0.9 \%$ normal saline and the spores of the other filamentous fungi were suspended in Tanquay buffer and then inoculated onto PDA plates. A sterile cork borer was used to make wells of $6 \mathrm{~mm}$ diameter on the MHA and of $13 \mathrm{~mm}$ diameter on PDA. The width of the zones of inhibition was recorded after incubation. In each of the wells in the culture plates previously seeded with the test organisms, $100 \mu \mathrm{l}$ aliquots of extract dilutions reconstituted in minimum amount of solvent at concentrations of 50 and 100 $\mathrm{mg} / \mathrm{ml}$ were applied. Sterile glycerol was used as a negative control. Wells containing $20 \mu \mathrm{l}$ aliquots of ciprofloxacin $(10 \mu \mathrm{g} / \mathrm{ml})$, streptomycin $(30 \mu \mathrm{g} / \mathrm{ml})$, nystatin $(10 \mathrm{mg} / \mathrm{ml})$ and amphotericin B $(10 \mathrm{mg} / \mathrm{ml})$ served as positive controls. Bacterial and Candida albicans cultures were incubated at $37^{\circ} \mathrm{C}$ for 18 to $24 \mathrm{~h}$ while the filamentous fungal cultures were incubated at $30^{\circ} \mathrm{C}$ for 36 to $48 \mathrm{~h}$. After incubation, antimicrobial activity was determined by measurement of the width of the zones of inhibition. For all the extracts, the tests were carried out in triplicate against each organism.

\section{Determination of minimum inhibitory concentration \& minimum microbicidal concentration}

The minimum inhibitory concentration (MIC) of the methanol extracts was determined for each of the test organisms in triplicate at concentrations of $3,6,9,12,15,20,25,50$ and $100 \mathrm{mg} / \mathrm{ml}$. To obtain these concentrations, $1 \mathrm{ml}$ aliquots of the extracts at double strength concentrations $(6,12,18,24,30,40,50$ and 200 $\mathrm{mg} / \mathrm{ml}$ ) were added to test tubes containing $1 \mathrm{ml}$ of nutrient broth for the bacteria and potato dextrose broth for the fungi. A loopful of the test organisms previously diluted to $0.5 \mathrm{McFarland}$ turbidity standards for bacterial isolates and 106 spores $/ \mathrm{ml}$ for fungal isolates was introduced to the respective tubes. The procedure was repeated using the standard antimicrobials ciprofloxacin, streptomycin, nystatin and amphotericin B instead of the extracts. A tube containing nutrient broth only was seeded with the test organisms to serve as a negative control. Tubes containing bacterial cultures were then incubated at $37^{\circ} \mathrm{C}$ for $24 \mathrm{~h}$ while tubes containing fungal spore cultures were incubated at $30^{\circ} \mathrm{C}$ for $36 \mathrm{~h}$. After incubation the tubes were examined for microbial growth by observing for turbidity. To determine the minimum microbicidal concentration (MMC), which includes minimum bactericidal (MBC) and minimum fungicidal concentrations (MFC), a loopful of broth was collected from those tubes which did not show any growth in the MIC determination and inoculated on sterile nutrient agar (NA) for bacteria and Sabourauds Dextrose agar (SDA) for fungi by streaking. To serve as a control, NA and SDA only were streaked with the respective test organisms. Plates inoculated with bacteria were then 
incubated at $37^{\circ} \mathrm{C}$ for $24 \mathrm{~h}$ while those inoculated with fungi were incubated at $30^{\circ} \mathrm{C}$ for $48 \mathrm{~h}$. After incubation, the concentration at which no visible growth was seen was recorded as the MBC and MFC respectively.

\section{Results}

The phytochemical characteristic of the extract is shown in table 1. Glycosides, alkaloids, saponins, tannins, flavonoids and volatile oil were extracted using ethanol and hot water. The antimicrobial activities of extracts of senna alata is shown in table 2. Streptococcus pyogenes and Staphyloccocus aureus were the most susceptible bacteria to all the extracts followed by Salmonella typhi and Escherichia coli. The most susceptible fungi species were Cryptococcus neoformans and Candida albicans while the least susceptible was Aspergillus flavus. The minimum inhibitory concentration $(\mathrm{mg} / \mathrm{ml})$ and minimum microbicidal concentration $(\mathrm{mg} / \mathrm{ml})$ of methanol extracts of senna alata is shown in table 3. The MIC and MMC of the extracts ranged between 3-10 $\mathrm{mg} / \mathrm{ml}$ and $15-50 \mathrm{mg} / \mathrm{ml}$ for the bacteria and fungi respectively while those for the antimicrobial agents ranged between $3-10 \mathrm{mg} / \mathrm{ml}$ and $6-50 \mathrm{mg} / \mathrm{ml}$ for the bacteria and fungi respectively as shown.

Table 1: Phytochemical characteristics of the whole extracts

\begin{tabular}{llll}
\hline \multicolumn{1}{l}{ Phytochemical constituent } & Ethanol Extract & Hot water Extract \\
\cline { 1 - 2 } Glycosides & + & + \\
Alkaloids & + & + \\
Saponins & + & - \\
Steroids & - & - \\
Tannins & + & - \\
Flavonoids & + & - \\
Resins & - & - \\
Volatile oil & + & - \\
\hline \multicolumn{2}{r}{} & & $-=$ absent
\end{tabular}

Table 2: Antimicrobial activities of extracts of senna alata

\begin{tabular}{|c|c|c|c|c|c|c|c|c|c|c|}
\hline \multicolumn{11}{|c|}{ Zone of inhibition (mm) } \\
\hline \multicolumn{3}{|c|}{ Roots extracts } & \multicolumn{3}{|c|}{ Leaf extracts } & \multicolumn{5}{|c|}{ Antimicrobial agents } \\
\hline Organisms & $\begin{array}{l}\mathbf{W} \\
\mathbf{E}\end{array}$ & $\begin{array}{l}\mathbf{M} \\
\mathbf{E}\end{array}$ & $\mathbf{A E}$ & WE & ME & $\begin{array}{l}\mathbf{A} \\
\mathbf{E} \\
\end{array}$ & $\begin{array}{l}\text { CIP } \\
(5 \mathrm{ug} / \mathrm{ml})\end{array}$ & $\begin{array}{l}\text { STN } \\
(15 \mathrm{ug} / \mathrm{ml})\end{array}$ & $\begin{array}{l}\text { AMP B } \\
(5 \mathrm{mg} / \mathrm{ml})\end{array}$ & $\begin{array}{l}\text { NYS } \\
(5 \mathrm{mg} / \mathrm{ml})\end{array}$ \\
\hline Escherichia coli & 4 & 4 & 3 & 3 & 4 & 3 & 9 & 8 & NA & NA \\
\hline Proteus mirabilis & 3 & 3 & 2 & 2 & 3 & 2 & 8 & 4 & NA & NA \\
\hline $\begin{array}{l}\text { Pseudomonas } \\
\text { aeruginosa }\end{array}$ & 3 & 3 & 3 & 3 & 3 & 3 & 6 & 3 & NA & NA \\
\hline Salmonella typhi & 3 & 4 & 4 & 3 & 4 & 4 & 9 & 4 & NA & NA \\
\hline Shigella flexneri & 3 & 4 & 3 & 4 & 4 & 4 & 11 & 9 & NA & NA \\
\hline Staphylococcus aureus & 4 & 4 & 4 & 5 & 5 & 5 & 24 & 11 & NA & NA \\
\hline $\begin{array}{l}\text { Streptococcus } \\
\text { Pyogenes }\end{array}$ & 5 & 6 & 5 & 6 & 6 & 5 & 10 & 9 & NA & NA \\
\hline Aspergillus flavus & 2 & 3 & 2 & 2 & 3 & 2 & NA & NA & 4 & 5 \\
\hline Aspergillus niger & 2 & 3 & 3 & 2 & 3 & 2 & NA & NA & 5 & 6 \\
\hline Candida albicans & 3 & 4 & 4 & 2 & 4 & 3 & NA & NA & 6 & 8 \\
\hline $\begin{array}{l}\text { Crptococcus } \\
\text { neoformans }\end{array}$ & 3 & 4 & 4 & 3 & 4 & 3 & NA & NA & 6 & 7 \\
\hline
\end{tabular}

$\mathrm{WE}=$ water $(\mathrm{Hot})$ extract, $\mathrm{ME}=$ methanol extract, $\mathrm{AE}=$ acetone extract, NYS = Nystatin,

$\mathrm{CIP}=$ ciprofloxacin, $\mathrm{STN}=$ streptomycin, $\mathrm{AMP} \mathrm{B}=$ amphotericin $\mathrm{B}$ and $\mathrm{NA}=$ not applicable.

Table 3: Minimum Inhibitory Concentration (mg/ml) and Minimum Microbicidal Concentration $(\mathrm{Mg} / \mathrm{MI})$ of Methanol Extracts of Senna alata

\begin{tabular}{|l|l|l|l|l|l|l|l|}
\hline \multicolumn{1}{|c|}{ Root Extracts Antimicrobial Agents } \\
\hline \\
\hline
\end{tabular}


Antimicrobial Qualities of Senna Alata

\begin{tabular}{|l|l|l|l|l|l|l|l|l|}
\hline Aspergillus flavus & 50 & 50 & 50 & 50 & NA & NA & 25 & 50 \\
\hline Aspergillus niger & 50 & 50 & 50 & 50 & NA & NA & 25 & 50 \\
\hline Candida albicans & 25 & 25 & 35 & 25 & NA & NA & 10 & 50 \\
\hline Cryptococcus neoformans & 6 & 6 & 13 & 13 & NA & NA & 6 & 13 \\
\hline
\end{tabular}

$\mathrm{CIP}=$ ciprofloxacin, $\mathrm{STN}=$ streptomycin, AMP B $=$ amphotericin B and NYS $=$ Nystatin.

\section{Discussion}

Phytochemical analyses revealed that Senna alata contained saponins, alkaloids, flavonoids, tannins, phenols and glycosides as shown in Table 1. The antimicrobial susceptibility testing shows that all the extracts (water, ethanol and alcohol) demonstrated significant activity against the bacteria and fungi (Table 2). Streptococcus pyogenes and Staphyloccocus aureus were the most susceptible bacteria to all the extracts followed by Salmonella typhi and Escherichia coli. The most susceptible fungi species were Cryptococcus neoformans and Candida albicans while the least susceptible was Aspergillus flavus. The results of MIC and MMC determination showed that the MIC and MMC of the extracts ranged between 3-10 mg/ml and 15-50 $\mathrm{mg} / \mathrm{ml}$ for the bacteria and fungi respectively while those for the antibiotics agent ranged between $3-10 \mathrm{mg} / \mathrm{ml}$ and $6-50 \mathrm{mg} / \mathrm{ml}$ for the bacteria and fungi respectively as shown in table 3. The highest activity of the plant (roots and leaves) was demonstrated by methanol extraction. Secondary metabolites present in plants have been reported by Rabe (2000) to be responsible for their therapeutic activity. Flavonoids and other physiochemical constitute of the plant also have antimicrobial properties and this is in agreement with Singh and Bhat, 2003 which reported that flavonoids are responsible for the antimicrobial activity associated with some ethnomedicinal plants which. Plant essential or volatile oils and their individual components have been used in traditional systems of medicines for a variety of bacterial infections for centuries and this is also in agreement with Rabe, 2000. Furthermore, it has been demonstrated that antibacterial properties of these oils can be attributed to their hydrocarbon and terpene constituents (Amit and Shailendra, 2006). The presence of glycosides and alkaloids in Musa sapientum peels may be attributed to their use by traditional medicine practitioners in healthcare systems in the treatment of some bacterial infections such as cough, fever, cold and venereal diseases (Ibrahim and Osman, 1995). The results of this research highlights the fact that the organic solvent (ethanol) extracts exhibited greater antimicrobial activity because the antimicrobial principles were either polar or non-polar and they were extracted more or only through the organic solvent medium. This observation agrees with the report of other investigators of medicinal plants that organic solvents are more suitable for extraction of phytochemicals (Singh and Singh, 2000; Natarajan et al., 2005). Different solvents have different solubility capacities for different phytoconstituents, hence the differences in the activities of the various extracts (Shanmugam et. al 2008). These bioactive compounds have been reported to be used by plants for protection against bacterial, fungal and pesticidal infections and are responsible for antimicrobial activity (Falodun et al., 2006). Pieme et al., 2006 investigated the antifungal and antibacterial activity of Cassia alata and got positive results. Low MIC is an indication of high efficacy of the plant extract while high MIC may indicate low efficacy or possible development of resistance by the microorganisms to the antimicrobial (Shanmugam et al 2008).

\section{Conclusion}

Despite the significant progress made in microbiology and the control of microorganisms, sporadic incidents of epidemics due to drug resistant microorganisms pose an enormous threat to public health. The use of medicinal plants with antimicrobial activities needs to be given more attention to arrest the situation. The demonstration of the antimicrobial activity of Senna alata in this work provides scientific basis for its use as a local health remedy. The plant can therefore be used in the treatment of gastrointestinal, urinary tract and wound infections as well as some mycotic infections. There is need for more research on the activity of the extracts against a wider range of bacteria and fungi and on the toxicology and further purification of the extracts for isolation of the pure active constituents. We believe that the result of this study will be an encouragement for further study that will lead to the use of the active components of Senna alata in drug preparation in the nearest future.

\section{References}

[1]. Abubakar, M. N., Ramanathan, R., Senthil, K. T. (2008). In vitro antifungal activities of Cassia alata Linn. Flower extract. Natural Product Radiance. 7(I): 6-9.

[2]. Alalor, C. A., Igwilo, C. I. and Jeroh, E. (2012). Evaluation of the antibacterial properties of aqueous and methanol extracts of Cassia alata. J. Pharm. and Allied Health Sci. 2(2): 40-46.

[3]. Amao, S. Y., Ajani, R.S. and Oladapo, O. (2010). Cassia alata alters Liver Structure in Rat. Afr. J. Biomed. Res. 13:231 - 233.

[4]. Dalziel, J.M. (1956). The Useful Plants of West Tropical Africa. Crown Agens, London, p: 612.

[5]. Daniels, R. and Knie, U. (2007). Galenics of dermal products vehicles, properties and drug release. J. Dtsch Dermatol Ges. 5:367381. 
[6]. El-Mahmood, A. M. and Doughari, J. H. (2008). Phytochemical screening and antibacterial evaluation of the leaf and root extracts of Cassia alata Linn. Afri J Pharm Pharmacol. 2 (7): 124-129.

[7]. El-Mahmood, A.M., Doughari, J. H. and Chanji, F. J. (2008). In vitro antibacterial activities of crude extracts of Nauclea latifolia and Daniella oliveri.. Sci. Res. Essays 3: 102-105.

[8]. Esimone, C.O., Nworu, C.S., Ekong, U.S. and Okereke, B. (2008). Evaluation of the antiseptic properties of Cassia alata-based herbal soap. Internet J Altern Med. 6(1):34-36.

[9]. Falodun, A., Okunrobe, L.O. and Uzoamaka, N. (2006). Phytochemical screening and anti-inflammatory evaluation of methanolic and aqueous extracts of Euphorbia heterophylla Linn. (Euphorbiaceae). African Journal of Biotechnology 5(6):529-531.

[10]. Ibrahim, D and Osman, H. (1995). Antimicrobial activity of Cassia alata from Malaysia. J. ethnopharmacol. 45 (3): $151-156$.

[11]. Idu, M., Omonigho, S. E. and Igeleke, C. L. (2007). Preliminary investigation on the Phytochemistry and antimicrobial activity of Senna alata L. Flower. Pak. J. Biol. Sci. 10: 806-809.

[12]. Khan, M.R., Kihara, M. and Omoloso, A.D. (2001). Antimicrobial activity of Cassia alata. Fitoterapia 72: $561-564$.

[13]. Ogunkwe, C.E., Oguzie,.E., E., Unaegbu, C.O and Okolue, B.N (2004). Phytochemical screening on the leaves of Sansevieria trifasciata. J. Chem. Soc. Nig. 29(1): 26-29.

[14]. Odunbaku, O. A. and Lusanya, O.A.F. (2011). Synergistic effect of ethanol leaf extract of Senna alata and antimicrobial drugs on some pathogenic microbes. Adv. Environ. Biol. 5: 2162-2165.

[15]. Odebiyi, O.O and Sofowora, E.A. (1978). Phytochemical Screening of Nigerian medicinal plants part II. Lloydia 41(1): 234-235

[16]. Palanichamy, S. and Nagarajan, S. (1990). Antifungal activity of Cassia alata leaf extract. J. ethnopharmacol. 29(3): 337-340.

[17]. Pieme C. A., Penlap, V. N., Nkegoum, B., Taziebou, C.L., Tekwu, E.M., Etoa, F.X. and Ngongang, J. (2006) Evaluation of acute and subacute toxicities of aqueous ethanolic extract of leaves of Senna alata (L.) Roxb (Ceasalpiniaceae). African Journal of Biotechnology 5 (3): 283-289

[18]. Reezal, I., Somchit, M.N. and Abdul Rahim, M. (2002). In Vitro Antifungal Properties of Cassia alata (Gelenggang Besar). Proceedings of the Regional Symposium on Environment and Natural Resources 10-11th April 2002, Hotel Renaissance Kuala Lumpur, Malaysia. 1: 654-659

[19]. Shanmugam, K., Holmquist, L., Steele, M., Stuchbury, G., Berbaum, K., Schulz, O., Benavente Garc'1a, O.,Castillo, J. Burnell, J., Garcia Rivas, V., Dobson, G. and M"unch, G. (2008). Plant-derived polyphenols attenuate lipopolysaccharide-induced nitric oxide and tumour necrosis factor production in murine microglia intoxification in rats. Journal of Ethnopharmacology 66: 355-361.

[20]. Singh, B and Bhat, T.K (2003) Potential therapeutic applications of some antinutritional plant secondary metabolites. Journal Agric . Food. Chem 51: 5579-5597

[21]. Singh, I. and V.P, Singh (2000) Antifungal properties of aqueous and organic solution extracts of seed plants against Aspergillus flavus and A.niger. Phytomorphol. 50: 151-157.

[22]. Trease, G.E and W.C Evans (1996). Pharmacognosy. Macmillan publishers 1td. Pp 213-832.

[23]. Villasenor, I.M., Canlas, A.P., Pascua, M.P.I., Sabando, M.N. and Soliven, L.A. (2002). Bioactivity studies on studies on Cassia alata Linn. leaf extract. Phytother Res. 16: 93-96. 